\title{
'n Beroepstudie van ekonome en bedryfsekonome
}

\author{
C.J. Kroon en J.R. Raubenheimer* \\ Departement Sielkunde, Randse Afrikaanse Universiteit, Posbus 524, Johannesburg 2000, Republiek van Suid-Afrika
}

Ontvang 12 April 1988; aanvaar 6 Junie 1988

\begin{abstract}
This paper first analyses the demographic data and training environment of South African university graduates in Economics and/or Business Economics on the basis of information extracted from the HSRC register of graduates. Next, it analyses the vocational diffusion, demographic data, and training environment of 3701 respondents, who responded to a postal questionnaire which was sent to 8760 white male university graduates in Economics and/or Business Economics during 1985. Special attention is paid to certain aspects of the occupational situation of practising economists and business economists, for example their employer sectors, occupational functions, the utilization of formal training in the work situation, fields of work, and the use of computer systems.
\end{abstract}

Hierdie artikel analiseer eerstens die demografiese data en opleidingsomgewing van Suid-Afrikaanse graduandi in Ekonomie en Bedryfsekonomie op grond van inligting bekom vanuit die RGN se register van graduandi. Daarna analiseer die artikel die werksverspreiding, demografiese data en opleidingsomgewing van 3701 repondente, wat geantwoord het op 'n vraelys wat aan 8760 blanke manlike graduandi gedurende 1985 gestuur is. Spesiale aandag word geskenk aan sekere aspekte van die beroepsituasie van praktiserende ekonome en bedryfsekonome, byvoorbeeld, hulle bedryfsektore, beroepsfunksies, die gebruik van formele opleiding in beroepsverband, werksvelde en rekenaartoepassing.

* To whom correspondence should be addressed

\section{Agtergrond en doelstelling}

Sedert die nywerheidsomwenteling van die negentiende eeu, het die tempo van kennisuitbreiding tot 'n groot aantal nuwe beroepsrigtings, asook ' $n$ verandering in die inhoud van die meeste beroepe gelei. Onder die omstan. dighede het suksesvolle beroepskeuse en -aanpassing, asook die samestelling van doeltreffende opleidingskursusse, ' $n$ ingewikkelde taak geword. In Suid-Afrika is toepaslike beroepslektuur egter baie beperk en hierdie is die eerste beroepstudie wat aandag gee aan die beroepseienskappe van die ekonoom en bedryfsekonoom. Die noodsaaklikheid van hierdie studie word beklemtoon deur te kyk na die skaarsheid van hoëvlakmannekrag wat meebring dat alle menslike hulpbronne in die RSA optimaal benut moet word; die belangrike rol wat die ekonoom en bedryfsekonoom (veral onder die huidige ekonomiese toestande) in die ekonomiese ontwikkeling van die RSA speel, hetsy as bydraers tot die aanbod van hoëvlak-mannekrag of potensiële entrepreneurs en beleidmakers; en die groot bedrae geld wat aan die opleiding van groot getalle persone in dié studierigtings besteë word. Die RGNRegister van Gegradueerdes toon dat Ekonomie reeds in 1970 die vierde gewildste hoofvak aan Suid-Afrikaanse Universiteite was.

Die doel van hierdie studie is om:

1. die doeltreffendheid van die opleiding vir die beroep van ekonoom en bedryfsekonoom en die praktiese benutting daarvan te bepaal, en

2. inligting oor fasette van die werksituasie van die beroep van ekonoom en bedryfsekonoom beskikbaar te stel.

\section{Navorsingsmetodiek}

Aangesien die beroepsgrense van persone in die ekonomiese rigting vaag is en omdat blanke mans $75 \%$ van die groep opgeleides in Ekonomie en/of Bedryfsekonomie uitmaak, is daar besluit dat die teikengroep alle blanke mans binne die RSA, wat oor ten minste 'n B-graad met Ekonomie en/of Bedryfsekonomie as hoofvak beskik, sou insluit.

Die RGN-Register van Gegradueerdes is as bron vir steekproeftrekking vir bogenoemde groep gebruik. Die steekproef $(N=8760)$ is soos volg saamgestel:

1. 'n $50 \%$-steekproef is van alle persone wat oor hoogstens 'n B-graad in Ekonomie en/of Bedryfsekonomie beskik, getrek $(n=3959)$.

2. alle nagraadse gegradueerdes wat oor minstens ' $n$ Bgraad in Ekonomie en/of Bedryfsekonomie beskik is by die ondersoek betrek $(n=4801)$.

'n Posvraelys is opgestel waarby vrae ingesluit is om inligting te verkry oor werkgewers, werkervaring, opleiding en benutting daarvan in die praktyk, beroepsbeoefening en -funksies, spanwerk, betrokkenheid by verenigings en beskikbare vakliteratuur. Die vraelyste, saamgestel met die hulp van 'n ad hocadvieskomitee en vooraf uitgetoets deur 'n vooropname op 220 persone, is gedurende April 1985 aan die steekproefpersone uitgestuur.

\section{Demografiese kenmerke en opleidingstruktuur van universum}

Ten einde 'n duideliker agtergrondbeeld te verkry waarteen die inligting van die respondente vertolk kan word, is die posisie van die groep blanke manlike opgeleides teenoor ander subgroepe soos die vroulike en anderskleurige opgeleides in die ekonomiese rigting, met behulp van gegewens uit die RGN-Register van Gegradueerdes, vergelyk.

Van die opgeleides in Ekonomie en/of Bedryfsekonomie is $83,5 \%$ mans en $90,3 \%$ blank, sodat blanke mans $75,1 \%$ van die groep uitmaak. Die anderskleuriges 
bestaan hoofsaaklik uit Indiërs $(64,3 \%)$. Van die blankes is $59 \%$ Afrikaanssprekend, teenoor die slegs $5 \%$ Afrikaanssprekende en 95\% Engelssprekende kleurlinge, Asiërs en swartes. Die mediaanouderdom van die totale group is 36 jaar, vir die vroulike opgeleides alleen is dit 29 jaar en vir die kleurlinge, Asiërs en swartes is dit 33 jaar. Die syfers is ' $n$ aanduiding van die toename van die populariteit van die studierigtings in die afgelope aantal jare, veral onder vroue en anderskleuriges.

Soos vir ander hoëvlakmannekrag is die meeste werkgeleenthede vir opgeleides in Ekonomie en Bedryfsekonomie in die stedelike sentra van die RSA beskikbaar. Van al die werkgeleenthede in die stedelike sentra is ongeveer die helfte in die PWV-gebied.

Van die totale groep opgeleides beskik slegs 7 uit elke 20 oor enige nagraadse kwalifikasies. Hiervan het amper $40 \%$ nagraadse kwalifikasies in Ekonomie en/of Bedryfsekonomie behaal, terwyl die res van die opgeleides oor nagraadse kwalifikasies in ander nieverwante studierigtings beskik.

Trotter (1981: 260-261) spreek sy kommer uit oor die tendens dat so 'n klein persentasie van die voorgraadse studente in Ekonomie tot nagraadse studie oorreed kan word. Hy voer verskeie verklarings hiervoor aan, byvoorbeeld die hoë aanvangsalarisse van Bgegradueerdes, die aanloklikheid van die beskerming en status van professionele beroepe in die Regte, Aktuariële Wetenskap en Rekeningkunde en die lae erkenning van die rol van die professionele ekonoom in die topbestuur van Suid-Afrika.

Gradueringstendense toon 'n toename in die aantal gekwalifiseerde persone in Ekonomie en Bedryfsekonomie. Meer as die helfte $(53,6 \%)$ van die kwalifikasies is sedert 1975 behaal, terwyl slegs $19,49 \%$ van die kwalifikasies in die eerste 64 jaar sedert 1900 behaal is. Bydraende faktore hiertoe is die groter belangstelling van vroue en anderskleuriges in die studierigtings - onderskeidelik $23,2 \%$ en $15,4 \%$ van alle kwalifikasies in Ekonomie en/of Bedryfsekonomie behaal deur vroue en anderskleuriges, is sedert 1980 verwerf. Daar is ook aanduidings in die gradueringstendense dat die probleemsituasie rondom die lae nagraadse studietendens besig is om te verbeter. Vir die tydperk 1970 tot 1984 was daar 'n gemiddelde jaarlikse groeikoers van 3,9\% vir kwalifikasies op B-graad vlak, teenoor $13,5 \%$ vir nagraadse kwalifikasies in Ekonomie en/of Bedryfsekonomie.

'n Ontleding van hoofvakkombinasies, toon dat die vyf gewildste hoofvakke onder opgeleides in die ekonomiese rigting in volgorde van populariteit die volgende is: Ekonomie, Bedryfsekonomie, Rekeningkunde, Bedryfsielkunde en Handelsreg. Die ontledings toon verder dat Ekonomie 'n meer populêre hoofvak as Bedryfsekonomie onder Engelssprekendes is, terwyl Bedryfsekonomie 'n meer populêre vak as Ekonomie onder Afrikaanssprekendes is. Laasgenoemde patroon kan moontlik daaraan toegeskryf word dat Bedryfsekonomie, in die konteks waarin dit op die Europese vasteland gedoseer word, naamlik as 'n selfstandige vakwetenskap, nie by sommige Engelsmedium universiteite in die land ingestel is nie, terwyl dit wel by
Afrikaansmedium universiteite die geval is.

Die hoofvakke hierbo genoem, kombineer feitlik deurgaans in die eerste drie plekke met mekaar. Kombinasies met buitevakke kom wel soms voor met byvoorbeeld Strafreg, Kosteberekening, Ouditkunde, Handel, Bedryfsosiologie, Sielkunde en Engels. Laasgenoemde toon die belangrike bydrae van verwante vakdissiplines soos die Regte, Rekeningkunde, Menswetenskappe en Tale tot Ekonomie en Bedryfsekonomie.

\section{Demografiese kenmerke en beroepsverspreiding van blanke manlike respondente}

Vanweë die gebrek aan duidelike riglyne by die definiëring van die kerngroep ekonome en bedryfsekonome, is daar besluit om die volgende as kriteria te stel vir die insluiting van respondente in dié groep:

1. die stamwoord 'ekonoom'/"bedryfsekonoom' moet in die beroepstitel van die respondent voorkom' of

2 . die aantal nagraadse respondente wat almal saam dieselfde beroepstitel deel, moet meer as 15 wees en $80 \%$ of meer van die groep moet hulself terselfdertyd as ekonome of bedryfsekonome beskou.

Die enigste uitsondering op die reël was die insluiting van die respondente met die beroepstitel 'ekonometrikus' by die kerngroep vanweë duidelike aanduidings in die literatuur (sien onder meer Common, 1976: 5) dat hul wel onder die kerngroep resorteer.

Opleiding in die ekonomiese rigting is nie beroepsgerig nie, gevolglik tree die opgeleides tot 'n groot verskeidenheid beroepe toe.

Van die opgeleides met hoogstens 'n B-graad en dié met nagraadse kwalifikasies in nie-verwante studierigtings tree onderskeidelik slegs $6,3 \%$ en $4,8 \%$ tot die beroep van ekonoom en bedryfsekonoom toe. Die grootste voedingsbron vir die kernberoepe is die opgeleides met nagraadse kwalifikasies in Ekonomie en/ of Bedryfsekonomie, waar een uit elke ses persone tot die kernberoepe toetree. Die grootste afsetgebied vir opgeleides is die bestuursberoepe - ongeveer drie uit elke tien opgeleides tree tot dié beroepsgroep toe. Die tweede grootste afsetgebied vir die opgeleides is die onderwysberoepe, die belangrikste ander beroepe waartoe opgeleides toetree is die van rekenmeester, prokureur, boer, personeelbeampte, ouditeursklerk en ingenieur.

Die belangrikste rede wat respondente wat voorheen wel ' $n$ ekonoom of bedryfsekonoom was, maar wat tans 'n ander beroep beoefen, vir hul beroepsverlating aanvoer, is dat hul belangstellings in ander beroepsrigtings soos bestuur, onderwys, boerdery en regte lê. Die huidige beroepsverspreiding van die beroepsverlaters stem met hierdie belangstellingsvelde ooreen. Gesien teen die agtergrond dat die helfte van die beroepsverlaters tot die bestuursberoepe toegetree het, klink die tweede grootste rede vir beroepsverlating, naamlik dat die nuwe beroepe beter bevorderingsgeleenthede ingehou het, geldig. Kritiek teen die werkinhoud en werkbevrediging van die beroep van 
ekonoom en bedryfsekonoom hou waarskynlik verband met die verplaasde belangstellingsvelde van die beroepsverlaters. Nog 'n rede vir beroepsverlating was klagtes dat die salarisse te laag is. Mediaaninkomstes van ekonome en bedryfsekonome vergelyk volgens 'n opname oor die loonstruktuur van gegradueerde blanke mans (Van Pletzen, 1984) egter baie goed met die van die totale groep blanke manlike gegradueerdes, alhoewel dit swakker is as die van die bestuursberoepe.

\section{Opleiding van blanke manlike respondente}

Die redes wat ekonome en bedryfsekonome met nagraadse kwalifikasies in nie-verwante studierigtings vir hul studiekeuse aanvoer, kan gebruik word om moontlike leemtes in die nagraadse kursussamestelling in Ekonomie en Bedryfsekonomie te identifiseer, wat kan dien as verdere verklaring vir die lae nagraadse, studiepatroon in laasgenoemde rigtings. Die belangrikste redes wat die respondente vir hul studiekeuses aanvoer is dat hul in anvullende gebiede tot Ekonomie en Bedryfsekonomie wou spesialiseer, dat hul die ander rigtings as gevolg van hul belangstelling daarin gekies het of dat hul hul bestuurs- en statistiekkennis wou verbreed. Van die groep wat die eerste rede aanvoer, het onderskeidelik $66,7 \%$ en $13,3 \%$ nagraadse kwalifikasies in Bedryfsadministrasie en Bedryfsrekeningkunde. Die groep wat hul bestuurskennis wou verbreed, het almal nagraadse kwalifikasies in Bedryfsadministrasie deur die grade MBA of MBL verwerf, terwyl die wat hul statistiekkennis wou verbreed, almal nagraads in Statistiek studeer het.

Hierdie patroon kan ' $n$ aanduiding daarvan wees dat die ekonome en bedryfsekonome 'n behoefte aan verdere gespesialiseerde opleiding in Bedryfsadministrasie en -bestuur, Rekeningkunde en Statistiek het en dat hulle dink dat kursusse soos MBA en MBL beter in die behoefte kan voorsien as suiwer nagraadse studie in Ekonomie en/of Bedryfsekonomie.

Die samestelling in opleidingspeil van die steekproef van hierdie ondersoek ondersteun weer eens die feit dat Engelssprekende mans swakker gemotiveer is tot nagraadse studie in Ekonomie en/of Bedryfsekonomie. 'n Verklaring hiervoor is moontlik dat $42,2 \%$ van die Engelssprekende opgeleides met hoogstens' $n$ B-graad in die bestuursberoepe is en dat dit die gewildste beroepskeuse in die groep is. Uit die aard van die saak is daar minder faktore om persone in sulke posisies tot verdere studie aan te spoor, as by persone wat nog na dié posisies streef.

Die uiteenlopende standpunte oor die hoofdoel van universitêre opleiding word deur Van der Merwe (1986: 13) opgesom: '. .. die taak van 'n dosent is om aan die student ' $n$ verwysingsraamwerk te gee, waarteen hy sy alledaagse praktiese ervaring kan ontleed.' Andersyds verwag sakelui " $n$ bepaalde opbrengs op hulle belegging in die onderwys in die vorm van toepaslik geskoolde mannekrag... wat kan verseker dat die produk kan ... onmiddellik in 'n bepaalde nis aangewend word.' Bosch (1984: 6) sê in dié verband: 'Dit is duidelik dat tydens kursusontwerp die uitdaging sterk is om enersyds voldoende erkenning te gee aan die fundamenteelteoretiese onderbou van die vak, maar andersyds, terselfdertyd ook die beklemtoning van die praktykgerigte aard van die ... leerstof.'

Ten einde bogenoemde situasie te ondersoek, is daar nagegaan of opgeleides hulle opleiding in Ekonomie en Bedryfsekonomie, slegs as agtergrondkennis benut en of dit direkte toepassing in hul beroepsbeoefening vind. Daar is gevind dat makro-ekonomiese teorie en monetêre ekonomie hoofsaaklik bydra tot agtergrondkennis, terwyl ekonomiese geskiedenis die laagste toepassingswaarde in die werksituasie het. Vakinhoude waarin meer as $70 \%$ van die respondente opleiding ontvang het en wat terselfdertyd 'n hoë spesifieke toepassingswaarde (bo 60\%) het, is Rekeningkunde, Statistiek, Finansiële en Ondernemingsbestuur en Ondernemingsfinansiering. Vakinhoude waarin 'n relatiewe lae persentasie respondente universiteitsopleiding ontvang het, maar wat volgens die respondente wat wel opleiding daarin ontvang het 'n hoë spesifieke toepassingswaarde het, is Administratiewe bestuur, Bedryfsadministrasie, Bedryfsielkunde, Wiskunde, Rekenaarwetenskap en Ekonomiese vooruitskatting.

Die hoë spesifieke toepassingswaarde van vakke soos Rekeningkunde, Statistiek, Bedryfsadministrasie en Administratiewe bestuur, bied 'n verklaring vir die gewildheid van die studierigtings onder ekonome en bedryfsekonome met nagraadse kwalifikasies in nieverwante rigtings. Die feit dat verskeie van die vakke met 'n hoë toepassingswaarde kwantitatiewe wetenskappe soos Wiskunde en Rekenaarwetenskap is, gee ' $n$ aanduiding van die toenemende bydrae van die deelgebiede tot Ekonomie en Bedryfsekonomie.

Werksaspekte waarin die grootste persentasie ekonome en bedryfsekonome 'n behoefte aan verdere opleiding het, is rekenaargebruik, statistiese tegnieke, bestuursvaardighede en beïnvloedings- en oorredingstegnieke. Eersgenoemde drie aspekte, tesame met personeelhantering, is die vier werksaspekte waarin die grootste persentasie van die res van die opgeleides die grootste behoefte aan verdere opleiding het.

Die behoefte aan opleiding in die eerste drie aspekte is te verwagte, gesien teen die hoë toepassingswaarde van opleiding in verskeie bestuursvakinhoude, Statistiek en Rekeningkunde, asook die lae opleidingsyfer in Rekenaarwetenskap en Administratiewe bestuur. Die behoefte aan verdere opleiding in Statistiek en bestuursvaardighede bied ' $n$ verdere verklaring vir die populariteit van rigtings soos Statistiek en Bedryfsadministrasie of -bestuur onder ekonome en bedryfsekonome met nagraadse kwalifikasies in nieverwante studierigtings.

\section{Werksituasie van blanke manlike respondente}

Die meerderheid werkgeleenthede vir ekonome en bedryfsekonome kom in die privaatsektor voor. Volgens 'n ooreenstemmingsanalise (Du Toit, et al. 1984) wat uitgevoer is, is relatief min ekonome en bedryfsekonome selfstandig werksaam - gemiddeld een uit elke tien. 
Wat die institusionele sektor betref, is dié beroepsgroep die nouste betrokke by ondernemings soos SAL, EOK, YSKOR, die monetêre owerheid, monetêre bankinstellings, versekeraars, pensioenfondse en ander finansiële instellings soos bouverenigings. Soos verwag kan word kom die nouste assosiasie by die beroepsgroep met die ekonomiese sektor finanswese voor.

Ooreenkomstig Duncan se rangorde-toets (Hirschovitz, 1984), assosieer die ekonome en bedryfsekonome die nouste met die aktiwiteit basiese navorsing van al die opgeleides. Die groep bestee gemiddeld meer as $60 \%$ van hul tyd aan basiese navorsing. Die aktiwiteite waarmee die meeste ekonome en bedryfsekonome (ongeveer agt uit elke tien) te doene $\mathrm{kry}$, is die identifikasie van probleemareas, insameling, ontleding en klassifisering van inligting en verslagskrywing. Die groep assosieer ook nouer as die res van die opgeleides met die aktiwiteite voorligting en advies en reis. Gemiddeld een tiende van hul tyd word onderskeidelik aan voorligting en adviesfunksies en bestuursaktiwiteite bestee. Opleidingspeil het geen beduidende effek op die tydsbesteding van ekonome en bedryfsekonome nie.

'n Ooreenstemmingsanalise toon dat daar 'n wye verskeidenheid terreine is waarbinne ekonome en bedryfsekonome kan spesialiseer. Ekonome en bedryfsekonome met hoogstens 'n B-graad bestee die meeste tyd aan aktiwiteitsbeoefening binne werksterreine finansies, administrasie en ondernemingsbestuur, terwyl dit ook die terreine is waarmee die meeste persone binne die groep kan verwag om in die loop van hul loopbaan mee te doene te kry. Die groep met nagraadse kwalifikasies bestee die meeste van hul tyd binne die terreine makro-ekonomie, ekonomiese groei en ontwikkeling en finansies, terwyl ongeveer die helfte van die groep kan verwag om met die terreine makro-ekonomie en owerheidsekonomie te doene te kry. Vir die groep met nagraadse kwalifikasies in nie-verwante studierigtings is die belangrikste twee terreine in terme van tydsbesteding en aantal persone wat daarmee te doene kry, ondernemingsbestuur en finansies.

Gemiddeld sewe uit elke agt ekonome en bedryfsekonome en sewe uit elke nege persone onder die res van die opgeleides in Ekonomie en Bedryfsekonomie maak van die rekenaar gebruik in hul werksituasie. Die hoë gebruiksfrekwensie, bied saam met die feit dat relatief $\min$ respondente universiteitsopleiding in rekenaargebruik ontvang het, 'n goeie verklaring daarvoor dat dit die werksaspek is waarin opgeleides die sterkste behoefte aan verdere opleiding voel.

Gemiddeld vier uit elke tien ekonome en bedryfsekonome het persoonlik direkte toegang tot die rekenaar vir gebruik daarvan, teenoor gemiddeld drie uit elke tien persone onder die res van die opgeleides. Die doel waarvoor die rekenaar die meeste aangewend word, deur gemiddeld meer as $70 \%$ van die opgeleides, is die berging van data of ontsluiting van gerekenariseerde materiaal. Ekonome en Bedryfsekonome met nagraadse kwalifikasies maak beduidend meer van die rekenaar gebruik as hulpmiddel in wiskunde en statistiese modelbou en die statistiese ontleding van data, as die res van die opgeleides. Bogenoemde hoë persoonlike gebruiksfrekwensie, asook die ingewikkeldheidsgraad van die rekenaargebruike, impliseer dat die opgeleides oor 'n relatief gevorderde vlak van rekenaarbehendigheid moet beskik.

Die feit dat gemiddeld $98 \%$ van die ekonome en bedryfsekonome van die hulp van spanlede gebruik maak, bevestig die feit dat spanwerk belangrik is. Die tipe spanlede waarmee ekonome en bedryfsekonome die meeste saamwerk is ander kollegas in die vak (gemiddeld $79,5 \%$ ), persone in die wiskundige en verwante beroepe soos statistici en rekenaarpersoneel (gemiddeld $69,9 \%$ ), persone in die bestuurs- en uitvoerende beroepe (gemiddeld 62,3\%), rekenmeesters (gemiddeld $54,1 \%$ ) en ingenieurs (gemiddeld $29,9 \%$ ). Dit is terselfdertyd die spanlede aan wie se bydrae die ekonome en bedryfsekonome die meeste waarde heg. Die hoë frekwensie van samewerking tussen ekonome en bedryfsekonome, asook die hoë premie wat daarop geplaas word, dui daarop dat die interafhanklikheid tussen ekonome en bedryfsekonome uit verskillende spesialiteitsgebiede net so belangrik as interdissiplinêre samewerking met ander professies is. Die belangrikheid en frekwensie van bydraes van persone uit die wiskundige wetenskappe beklemtoon weer eens die belangrike insette van die kwantitatiewe wetenskappe tot Ekonomie en Bedryfsekonomie.

Die lae betrokkenheid van ekonome en bedryfsekonome by die organisering van hul beroep, word weerspieël deur die feit dat slegs gemiddeld $49,4 \%$ van die groep aan enige professionele beroeps-, of vakverenigings behoort. Ekonome en Bedryfsekonome met nagraadse kwalifikasies in Ekonomie en/of Bedryfsekonomie toon egter 'n beduidende hoër betrokkenheid by verenigings in die algemeen $(56,4 \%$ teenoor $45,9 \%$ ), asook by verenigings in hul eie gebied $(51,9 \%$ teenoor $23,9 \%)$, as die res van die ekonome en bedryfsekonome.

Vakliteratuur het die belangrike funksie om opgeleides binne daardie vakgebied op hoogte te hou met die jongste ontwikkelinge binne die samelewing en hul vakgebied. Gemiddeld vier uit elke tien respondente toon egter aan dat daar leemtes in die plaaslike artikels oor ekonomie en bedryfsekonomie bestaan. Die verskeidenheid terreine wat die opgeleides in hul literatuur gedek sou wou hê, weerspieël weer eens die verskeidenheid van terreine waarin die opgeleides kan spesialiseer. Die feit dat algemene bestuur, bemarkingspersoneel- en finansiële bestuur deur al die groepe geïdentifiseer word as van die terreine waarop die grootste leemtes in die literatuur voorkom, sluit daarby aan dat bestuursvaardighede en personeelhantering ook die aspekte was waarin die opgeleides die grootste behoefte aan verdere opleiding gehad het. Dit is ook in ooreenstemming met die bevinding dat die vakinhoud van bogenoemde terreine 'n relatiewe hoë spesifieke toepassingswaarde in die opgeleides se werksituasie het. 


\section{Summary}

The purpose of the research on which this paper is based, was twofold: (i) to determine the effectiveness of training for the professions of economist and business economist, and (ii) to disseminate information about the work situation of these professions, for inter alia career counseling purposes.

During 1985 a postal questionnaire was sent to 8760 university graduates in Economics and/or Business Economics, of whom 3701 responded.

In order to furnish a background against which the respondents' information can be interpreted, the paper initially surveys certain characteristics of the university graduates in Economics and/or Business Economics. The demographic data (sex, race, colloguial usuage, age structure, geographical distribution) and training environment (qualification structure, graduate tendency, prevalent major subject combinations) were analysed on the basis of information extracted from the Human Sciences Research Council's Register of Graduates.

Firstly, the vocational diffusion of the respondents were analysed. Graduating tendencies show an increase in the total number of qualifications in Economics and Business Economics, and more specifically regarding women and non-whites. The median age of the respondents was 36 years. Most of the career opportunities were available in metropolitan areas, with more than half of these in the PWV area.

As far as the training environment of the respondents was concerned, interesting information came to the fore. The five most popular subject combinations were Economy, Business Economy, Accountancy, Industrial Psycology and Commercial Law. Results indicate that only a minor group of the graduates in Economics and/or Business Economics eventually practise as an economist or business economist. Approximately one third of all respondents enter a managerial position, with the teaching profession second in line.

Poor post-graduate figures for bachelor's level graduates in Economics and Business Economics are reported in favour of advanced qualifications in Accountancy, Statistics, Management Administration and Computer Science. It is in these fields of knowledge that a lack of background in basic training is reported.

These analyses were done in groups on the basis of the respondents' graduate level (at most a B-degree, postgraduate qualifications in Economics and/or Business Economics, post-graduate qualifications in non-related study fields) and their current professional status (economists, business economists, managerial positions, educational and related professions, and others).

In the papaer special attention is also paid to certain aspects of the occupational situation of practising economists and business economists, namely their employer sectors, occupational functions, the utilization of formal training in the work situation, fields of work where occupational functions are exercised, utilization, the use of computer systems in the work situation, teamwork, membership of professional associations, and the need for topical articles in local literature on Economics or Business Economics.

Training levels achieved were used as a demarcator, throughout. Where appropriate, the above-mentioned characteristics of economists or business economists are equated with the rest of those trained in Economy and Business Economy.

\section{Verwysings}

Bosch, J.K. 1984. Gegradueerdes in die Bedryfsekonomie Quo Vadis? Referaat gelewer by die Konferensie vir ekonome en bedryfsekonome, Pretoria.

Common, M.S. 1976. Basic econometrics: An introductory text for economemists. London: Longman.

Hirschowitz, R. 1984. The work situation of a group of natural science graduates. Pretoria: Human Sciences Research Council.

Raad vir Geesteswetenskaplike navorsing. Instituut vir Mannekragnavorsing. Gegewens op die RGN-Register van Gegradueerdes.

Trotter, G.J. 1981. The supply of economists. S. Afr. J. Econ., vol.49, 256-268.

Van Pletzen, J.C. 1984. Die loonstruktuur van gegradueerde blanke mans in 1984. Pretoria: Raad vir Geesteswetenskaplike Navorsing. 